\title{
NATURAL MONUMENTS OF SELECTED SPECIES OF THE GENUS SORBUS L. IN POLAND
}

\author{
LESZEK BEDNORZ \\ L. Bednorz, Department of Botany, Poznań University of Life Sciences, Wojska Polskiego 71 C, 60-625 \\ Poznań, Poland, e-mail: lbednorz@up.poznan.pl
}

(Received: May 29, 2014. Accepted: August 25, 2014)

\begin{abstract}
AвSTRACт. This paper describes 10 natural monuments, including 12 specimens of rowan trees, representing three following species: Sorbus aria (2), S. aucuparia (7) and S. latifolia (1). It also presents a comprehensive analysis of all rowan trees admitted as natural monuments in Poland.
\end{abstract}

KEY WORDS: monuments of nature, trees, rowans, Sorbus

\section{INTRODUCTION}

The genus Sorbus L. (Rosaceae) comprises approx. 250 species found mainly in the temperate zone of the Northern Hemisphere (PHIPPs et al. 1990). In Poland we currently distinguish seven species of rowans: common whitebeam - S. aria (L.) Crantz, European rowan (mountain ash) - S. aucuparia L. Emend. Hedl., Carpathian whitebeam - S. carpatica Borbás, dwarf whitebeam - S. chamaemespilus (L.) Crantz, Balkan whitebeam - S. graeca (Spach) Kotshy, Swedish whitebeam $-S$. intermedia (Ehrh.) Pers. and wild service tree $-S$. torminalis (L.) Crantz (MireK et al. 2002). Among them only European rowan is a species frequently found throughout Poland. The other species need to be considered as rare, mostly with a very limited range. Two among the native species, $S$. intermedia and S. torminalis, are covered by legal species protection and their selected populations are additionally protected in reserves. Apart from the native species in green areas, we may also find several alien species. The most frequent include: showy mountain ash - S. decora (Sarg.) Schneid., Koehne mountain ash $-S$. koehneana Schneid., service tree of Fontainebleau - S. latifolia (Lam.) Pers., Japanese rowan - S. commixta Hedl. and bastard service tree S. $\times$ thuringiaca (Ilse) Fritsch (CZEKALSKI 2002).

Natural monuments are the oldest forms of nature conservation both worldwide and in Poland. Among Polish natural monuments, which list com- prises at present approx. 35 thousand items, single trees growing in forests and outside forested areas are definitely predominant, at over 27 thousand. Old and spectacular trees are also protected as clusters or avenues. The status of natural monument may be granted not only to specimens of native tree species, but also old trees of alien species (Symonides 2007). Generally trees with circumferences (at breast height, i.e. $130 \mathrm{~cm}$ ) exceeding $100 \mathrm{~cm}$ are granted the natural monument status in the case of rowans.

Rowans protected in Poland as natural monuments represent five species: Sorbus aria, S. aucuparia, S. intermedia, S. latifolia and S. torminalis. A list of natural monument trees for Swedish whitebeam $S$. intermedia and wild service tree $S$. torminalis were presented in earlier publications by the author of this study (Bednorz 2010, Bednorz \& Ludjan 2012). The aim of this paper is to provide information concerning monument rowans representing the other Sorbus species found in Poland.

\section{RESULTS AND DISCUSSION}

The paper lists natural monuments representing the following rowan species: Sorbus aria, S. aucupar$i a$ and S. latifolia (Table 1). Service tree of Fontainebleau $S$. latifolia, which is a hybrid formed by crossing common whitebeam $S$. aria and wild service tree S. torminalis, is not found in Poland in the wild. The other two species are native to Poland. 
Table 1. List of rowan trees recognised as natural monuments

\begin{tabular}{|c|c|c|c|c|c|}
\hline Province & Location & $\begin{array}{l}\text { Number } \\
\text { of trees }\end{array}$ & $\begin{array}{l}\text { Circum- } \\
\text { ference } \\
(\mathrm{cm})\end{array}$ & $\begin{array}{l}\text { Year of } \\
\text { regis- } \\
\text { tration }\end{array}$ & Comments \\
\hline \multicolumn{6}{|c|}{ Sorbus aria } \\
\hline Dolnośląskie & Lubań, Mickiewicza 4 & 1 & 131 & & In domestic premises \\
\hline Śląskie & Cieszyn, Bielska 4 & 1 & 136 & 1998 & In the Hospital Park \\
\hline \multicolumn{6}{|c|}{ Sorbus aucuparia } \\
\hline Dolnośląskie & $\begin{array}{l}\text { Wałbrzych commune, Szczawno Zdrój, } \\
\text { Wojska Polskiego } 2\end{array}$ & 1 & 120 & 1995 & Square in front of domestic premises \\
\hline Łódzkie & $\begin{array}{l}\text { Skierniewice commune, } \\
\text { avenue linking Julków-Dębowa Góra- } \\
\text { Ludwików }\end{array}$ & 3 & $130-140$ & 1997 & Mixed species avenue of trees \\
\hline Mazowieckie & Warszawa, Solidarności 101-105/111b & 1 & 110 & 1996 & \\
\hline Podlaskie & $\begin{array}{l}\text { Bielsk Podlaski commune, Dobromil, } \\
\text { former manor park }\end{array}$ & 1 & 55 & 1998 & Mixed species avenue of trees \\
\hline \multirow[t]{3}{*}{ Wielkopolskie } & $\begin{array}{l}\text { Czerwonak commune, along the Wierzon- } \\
\text { ka-Mielno road }\end{array}$ & 1 & 70 & 2003 & Mixed species avenue of trees \\
\hline & Kościan commune, Krzan plot 7057/1 & 1 & 92 & 2009 & \\
\hline & $\begin{array}{l}\text { Kórnik commune, along the Kromolice-- } \\
\text { Zimin road }\end{array}$ & 1 & 38,34 & 2001 & $\begin{array}{l}\text { Mixed species avenue of trees, } \\
\text { a double-trunk specimen }\end{array}$ \\
\hline \multicolumn{6}{|c|}{ Sorbus latifolia } \\
\hline Wielkopolskie & $\begin{array}{l}\text { Czerwonak commune, along the Wierzon- } \\
\text { ka-Mielno road }\end{array}$ & 1 & 163 & 2003 & Mixed species avenue of trees \\
\hline
\end{tabular}

Common whitebeam Sorbus aria, found in Poland in the wild only in the Tatra and the Pieniny Mountains, is represented by only two natural monuments. Both specimens are growing in urban green areas in southern Poland.

European rowan Sorbus aucuparia, found commonly throughout Poland, is represented by scarce natural monuments. There are only seven of them comprising a total of nine trees. Only one natural monument specimen is growing in the natural locality; the others are elements of green areas.

Only one specimen of service tree of Fontainebleau Sorbus latifolia has been granted the natural monument status. It is a tree with a circumference of $136 \mathrm{~cm}$, growing in a mixed species roadside avenue near Poznań.

The greatest numbers of natural monument rowans in Poland are found for wild service trees (50 natural monuments comprising 179 trees) and Swedish whitebeams (24 natural monuments comprising 471 trees; BeDnorz 2010, BeDnorz \& LudjAn 2012). In the case of wild service tree, the natural monument status is granted most frequently to single, spectacular trees, less frequently their clusters, growing almost exclusively in forests in natural localities. In turn, in the case of Swedish whitebeam all recognised natural monuments are elements of urban or non-urban green areas and were planted as such. There are no natural monuments of this species growing in natural localities. Natural monuments include not only single trees or their clusters, but also avenues composed either solely of Swedish whitebeams or mixed species avenues containing Sorbus intermedia. A comparison of diameters breast high for rowans granted the natural monument status shows that the biggest are found in Swedish whitebeams and wild service trees, exceeding $200 \mathrm{~cm}$. Among the registered natural monument trees of $S$. intermedia, the largest trunk circumference at breast height, i.e. $275 \mathrm{~cm}$, is recorded for a specimen growing in a roadside avenue in the Pruszcz commune (Bednorz \& Ludjan 2012). At present the thickest natural monument wild service tree in Poland, with a stem circumference of $226 \mathrm{~cm}$ (at a height of $115 \mathrm{~cm}$ ), is growing in the Jamy Forest Division (BeDnorz 2010). The thickest European rowan recognised as a natural monument, with a trunk circumference of $140 \mathrm{~cm}$, is growing in the Skierniewice commune in a mixed species roadside avenue of trees.

The number of natural monuments comprising rowans growing in Poland is relatively low, only 84. However, it does not mean that there are so few spectacular rowan specimens in our country. The number of trees of species from the genus Sorbus, which have reached natural monument dimensions, is much greater. Numerous surveys concerning dendroflora in different objects (e.g. urban green, historical parks) or regions of Poland indicate the presence of the socalled monumental trees, i.e. having the dimensions of natural monuments, but not covered by this form of legal protection. However, most frequently an indication of monumental trees is not connected with a motion to have the listed objects formally granted the natural monument status. 


\section{REFERENCES}

BEDNORz L. (2010): Jarząb brekinia Sorbus torminalis (L.) Crantz w Polsce. Bogucki Wydawnictwo Naukowe, Poznań.

Bednorz L., Ludjan J. (2012): Pomnikowe jarzęby szwedzkie Sorbus intermedia w Polsce. Chrońmy Przyrodę Ojczystą 68, 5: 378-382.

CzeKalski M. (2002): Drzewo roku 2002 - Jarząb. Gatunki i odmiany zagraniczne. Szkółkarstwo 4: 7-10.
Mirek Z., Pię́Koś-Mirkowa H., Zając A., Zając M. (2002): Flowering plants and pteriodophytes of Poland. A checklist. Krytyczna lista roślin naczyniowych Polski. W. Szafer Institute of Botany, Polish Academy of Sciences, Kraków.

Phipps J.B., Robertson K.R., Smith P.G., Rohrer J.R. (1990): A checklist of the subfamily Maloideae (Rosaceae). Canadian Journal of Botany 68: 2209$-2269$.

Symonides E. (2007): Ochrona przyrody. Wydawnictwa Uniwersytetu Warszawskiego, Warszawa. 